IJLRES - International Journal on Language, Research and Education Studies

ISSN: 2580-6777 (p); 2580-6785 (e)

DOI: $10.30575 / 2017 /$ IJLRES-2018050806

Vol. 2, No. 2, 2018

Page: $218-227$

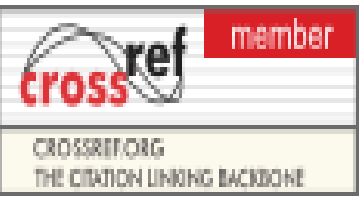

\title{
THE EFFECT OF SELF-CONCEPT ON THE MATHEMATICS LEARNING ACHIEVEMENT
}

\author{
Rosliana Siregar \\ Department of Mathematics Education, Faculty of Education and Teachers Training \\ Islamic University of North Sumatra, Indonesia \\ Roslianasrg20@gmail.com
}

Fadhilla Humairo

Department of Mathematics Education, Faculty of Education and Teachers Training Islamic University of North Sumatra, Indonesia

Fadhilahuamiro@gmail.com

\begin{abstract}
This study aims to determine the effect of self-concepts on mathematics learning achievement of students of class X at State Senior High School 14 Medan. The population in this study is all students of class X State Senior High School 14 Medan which amounted to 304 students. Technique of sampling using technique of Proportionate Stratified Random Sampling counted 40 student for research sample. Data collection using questionnaire method and documentation method. Data analysis technique used is regression analysis, correlation analysis and $t$ test with significance level of 5\%. Testing data in this study using the help of SPSS 15 for Windows program for each test result. The results showed that there is a significant influence between self-concept and mathematics learning achievement obtained from the $t$ count $(3,572)>$ $t$ table (1.68), with a probability significance of $0.01<0.05$. The magnitude of the determination coefficient of $25.1 \%$.
\end{abstract}

Keywords: Self-Concept, Mathematics Learning, Achievement

\section{INTRODUCTION}

The rapid development of science and technology demands quality Indonesian human resources. Therefore, one of the government's efforts to improve the quality of human resources is by striving to improve the quality of education, so that, can produce graduates who are more qualified and able to face challenges.

One of the subjects that became the standard of graduation in every level of education is mathematics. Therefore, mathematics can be said as a very important lesson and very instrumental in efforts to improve the quality of education in Indonesia. However, negative opinions about mathematics have evolved and are inherent in society, especially students. Mathematics is considered a difficult lesson, with many 


\section{The Effect of Self-Concept on the Mathematics Learning Achievement DOI: 10.30575/2017/IJLRES-2018050806}

abstract mathematical formulas making students dislike mathematics. It can have a negative impact on the student's own behavior. Students who do not like mathematics tend to be lazy to learn it and sometimes take shortcuts like cheating to get the job done without first learning it. This can affect student achievement.

From the results of observations in State Senior High School 14 Medan through the results of the initial questionnaire test also found that the success rate of students in self-understanding of $57.57 \%$ (moderate). This can be interpreted that the level of students' understanding of self-concept is still relatively moderate, in other words the students are still not too understand the self-concept contained within them.

In the process of learning, teachers will be faced with a number of characteristics of students who diverse. There are students who can take or follow the learning activities smoothly, and on the other hand there are students who have difficulty in following these activities. Students who lack understanding of self-concept contained in him can negatively impact the way of learning, so that indirectly affect the learning achievement.

\section{LITERATURE REVIEW}

Factors that influence the level of learning achievement include: self-concept, locus of control, anxiety experienced, and motivation of learning outcomes. Self-concept is one of the factors that affect student achievement ${ }^{1}$. Self-concept is all perception of one's self aspect which covers physical aspect, social aspect, and psychological aspect, based on experience and interaction of herself with others ${ }^{2}$.

Meanwhile, the physiological aspect is a person's view of his physical appearance including limbs, clothing, objects and facilities owned. Psychological aspects include one's image, judgment, and expectation of one's own thoughts, feelings and behaviors. The social aspect is the mind and behavior that a person takes as a general response to others and society. Social aspects include social interaction and social roles ${ }^{3}$. From various aspects in self-concept can also be explained that the concept of self has an influence on the achievement of learning mathematics. For example: when viewed from aspects of psychology are, among others, thoughts, feelings, and attitudes. The mind has

\footnotetext{
1 Soemanto. 2006. Psikologi Pendidikan. Jakarta: Rineka Cipta. P. 34

2 Sobur, Alex. 2013. Psikologi Umum. Bandung: Pustaka Setia. P. 507

${ }^{3}$ Rakhmat, Jalaluddin. 2005. Psikologi Komunikasi. Bandung: PT Remaja Rosda Karya. P. 26
} 
the power of being able to make one's student spirit. He will study hard to stay up to achieve success. The mind also has the opposite power: making a student dislike of the lessons and the teacher. He does not have the spirit to achieve achievement to get a low score and not go up the class.

The concept of self depends very much on the way in which a person compares himself with others. Self-concept has an important role in determining student achievement ${ }^{4}$. This can be seen through the student's own view of himself. If the student views himself as a person who has enough ability to perform a task, then all the behavior of the student will show the sense of ability. Vice versa, if the students see themselves as people who do not have enough ability to perform a task, then all the behavior of students will show the incompetence. Thus, students do not believe in the capabilities that exist in itself. It does not directly affect the student's learning achievement.

According to Rachmat, there are two types of self-concept that someone has, namely positive self concept and negative self concept ${ }^{5}$. The following characteristics of a person with positive self-concept and negative self-concept identified by Brooks and Emmert is a person who has a positive self-concept is characterized by five things: He is convinced of his ability to overcome problems, he feels equal to others, he receives praise without shame, he realizes that everyone has a variety of feelings, desires and behaviors that are not entirely approved by the public, able to improve himself because he is able to express aspects of the personality he does not like and try to change. Conversely, there are 4 (four) signs of people who have a negative self-concept. First. He is sensitive to criticism. Secondly, people who have a negative self-concept, are very responsive to praise. Third, the person whose self-concept is negative, tends to feel unpopular with others. Fourth, people who concept themselves negative, pessimistic about the competition as revealed in their reluctance to compete with others in making achievements 6 .

Yuan Andinny states that to achieve success in mathematics lessons is to give positive thoughts to students on the results they achieve, and explain to students that positive thinking is one way to learn to achieve goals. In cultivating positive thinking

\footnotetext{
${ }^{4}$ Khodijah, Nyayu. 2014. Psikologi Pendidikan. Jakarta: PT Raja Grafindo Persada. P. 90

${ }^{5}$ Rakhmat, Jalaluddin. 2005. Psikologi Komunikasi. Bandung: PT Remaja Rosda Karya p. 105

${ }^{6}$ Ibid. P. 107
} 
about mathematics, a teacher must also pay attention to the way the delivery of the material to be easily understood. As well as explaining the function or benefit of learning mathematics is to make it easier to understand other lessons because mathematics is "Queen Of Science"7.

\section{METHODOLOGY}

This research is conducted at State Senior High School 14 Medan on 2017. This research is a correlational research that aims to determine the effect of selfconcepts on mathematics learning achievement of students of class $\mathrm{X} v$. The population in this study is all students of class X State Senior High School 4 Medan which amounted to 304 students. The sampling technique using Proportionate Stratified Random Sampling technique was taken by 40 students for the research sample.

Data collection using questionnaire method and documentation method, for the mathematics learning achievement variable obtained from the result of math test even semester given to the students. While for self concept variable is obtained from questionnaire given to sample or respondent that have been validated. Data analysis technique used is regression analysis, correlation analysis and $t$ test with significance level of 5\%. This study uses SPSS 15 for Windows program for each test result.

Statistic

\begin{tabular}{|c|c|c|c|}
\hline & & Self-Concept & $\begin{array}{c}\text { Learning } \\
\text { Achievement }\end{array}$ \\
\hline \multirow[t]{2}{*}{$\overline{\mathrm{N}}$} & Valid & 40 & 40 \\
\hline & Missing & 0 & 0 \\
\hline \multicolumn{2}{|c|}{ Mean } & 104,28 & 78,18 \\
\hline \multicolumn{2}{|c|}{ Median } & 106,50 & 78,00 \\
\hline \multicolumn{2}{|c|}{ Mode } & 107 & 76 \\
\hline \multicolumn{2}{|c|}{ Std. Deviation } & 12,304 & 2,374 \\
\hline \multicolumn{2}{|c|}{ Minimum } & 79 & 75 \\
\hline \multicolumn{2}{|c|}{ Maximum } & 133 & 85 \\
\hline \multicolumn{2}{|c|}{ Sum } & 4171 & 3127 \\
\hline
\end{tabular}

7 Andinny, Yuan. 2013. Pengaruh Konsep Diri dan Berpikir Positif terhadap Prestasi Belajar Matematika Siswa. Jurnal: Fakultas Teknik, Matematika dan IPA Universitas Indraprasta PGRI. P. 128 


\section{FINDINGS AND DISCUSSION}

\section{Research Finding Description}

The research that has been conducted in class X State Senior High School 14 Medan shows that for self concept variable with average value equal to 104,28; maximum value 133; minimum value 79 with standard deviation 12,304. Meanwhile, for the learning achievement variable with an average value of 78.18 ; maximum value 85 ; a minimum value of 75 with a standard deviation of 2,374 which can be seen in the following table:

Statistic

\begin{tabular}{|c|c|c|c|}
\hline & & Self-Concept & $\begin{array}{c}\text { Learning } \\
\text { Achievement }\end{array}$ \\
\hline \multirow[t]{2}{*}{$\bar{N}$} & Valid & 40 & 40 \\
\hline & Missing & 0 & 0 \\
\hline \multicolumn{2}{|c|}{ Mean } & 104,28 & 78,18 \\
\hline \multicolumn{2}{|c|}{ Median } & 106,50 & 78,00 \\
\hline \multicolumn{2}{|c|}{ Mode } & 107 & 76 \\
\hline \multicolumn{2}{|c|}{ Std. Deviation } & 12,304 & 2,374 \\
\hline \multicolumn{2}{|c|}{ Minimum } & 79 & 75 \\
\hline \multicolumn{2}{|c|}{ Maximum } & 133 & 85 \\
\hline \multicolumn{2}{|c|}{ Sum } & 4171 & 3127 \\
\hline
\end{tabular}

Based on the results of data analysis above it can be obtained the results of a descriptive test that overall self-concept students of $67.5 \%$ are at the level of the category is. This means that most of the students' self-concept is in the medium category. Students who have self-concept in the medium category can be interpreted that the student has positive self-concept and negative in him.

Similarly, students' mathematics learning achievement of $77.5 \%$ is at the medium category level. It can be argued that most students have achievements in the moderate category. Students who have achievement in the moderate category can be interpreted that the student has achievement in achievement that is between the values in the high category and low category. This can be seen in the picture below:

\begin{tabular}{|c|c|c|}
\hline Variabel & Asymp. Sig & $\boldsymbol{a}$ \\
\hline Konsep Diri $\left(\mathrm{X}_{1}\right)$ & 0,894 & 0,05 \\
\hline Prestasi Belajar $(\mathrm{Y})$ & 0,368 & 0,05 \\
\hline
\end{tabular}

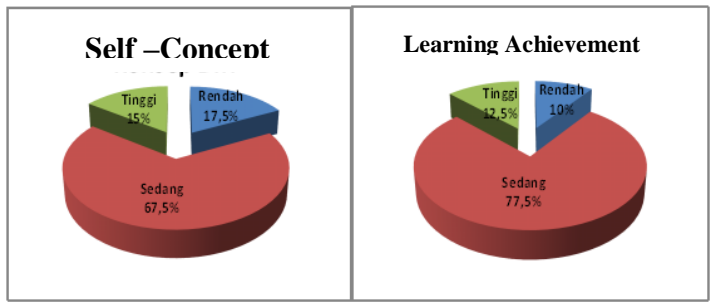


Self -concept variables can not only be seen as a whole. However, self-concept assessments can also be viewed based on aspects of self-concept obtained through questionnaire tests to students. Aspects of self-concept consists of 3 (three) aspects, namely: physical aspects, psychological aspects, and social aspects. Based on the percentage obtained that the psychological aspect has the largest percentage compared to other aspects, that is $40.6 \%$.

\section{The Requirement Analysis Test}

Linearity test results based on the regression equation formed between the three variables is linear, where if the value of Fhitung < Ftabel then there is a linear relationship between independent variables $(\mathrm{X})$ with bound $(\mathrm{Y})$. Linearity test results can be seen in the following table:

\begin{tabular}{|c|c|c|c|c|c|c|}
\hline \multicolumn{3}{|c|}{ I Variable } & \multirow{2}{*}{ Dh } & \multirow{2}{*}{ F Fitung } & \multirow{2}{*}{$F_{\text {taplel }}$} & \multirow{2}{*}{ Result } \\
\hline 0 & & ound & & & & \\
\hline 1 & $X_{1}$ & Y & $25 \| 3$ & 0,988 & 2,14 & Linien" \\
\hline
\end{tabular}

Therefore, it can be continued by using parametric statistics with regression and multiple correlation

\section{The Hypothesis Test}

Testing the hypothesis with simple linear regression as follows: $\hat{Y}=68,089+$ 0,097X1, from the regression equation it is seen that the relationship of self-concept with the achievement of learning mathematics 14 State Senior High School 4 Medan's students is the direction (positive). This is shown in the regression coefficient or b value in the regression equation which shows a positive number of 0.097 which means that if the self-concept increases 1 unit, then the achievement of learning mathematics will go up by 0,097. Similarly, if the self-concept decreased 1 unit, then the mathematics learning achievement will decrease by 0,097 . Here's a simple linear regression chart of selfconcept relationship with learning achievement. 
Normal P.P Plot of Regression Standardized Residual

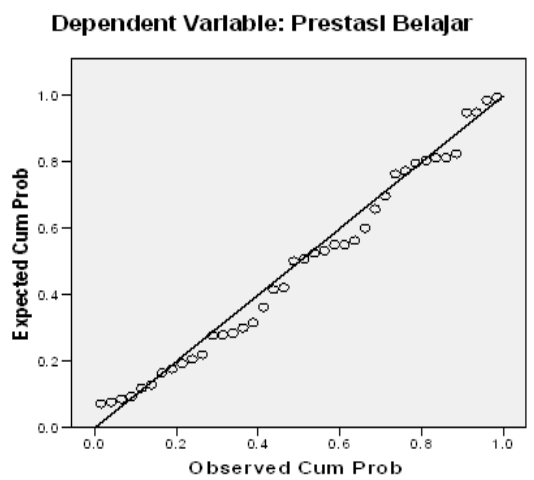

In the result of hypothesis test obtained from tcount $(3,572)>$ ttabel $(1,68)$, with probability significance $0,01<0,05$. Correlation $\mathrm{X} 1$ with $\mathrm{Y}$ obtained $\mathrm{r}$ equal to 0,501 , mean self concept relationship with mathematics learning achievement of student of State Senior High School 14 Medan is enough. This shows that self concept has enough relation to student achievement. The amount of contribution (contribution) from self concept variable with student achievement of State Senior High School 14 Medan is $25,1 \%$.

Description of research result obtained that from three aspect in self concept, percentage of psychology aspect is biggest amount that is equal to $40,6 \%$ compared with physical aspect equal to $28,5 \%$ and social aspect equal to $30,8 \%$. It can be said that the psychological aspects have a greater influence on students in learning mathematics than other aspects. These psychological aspects include thoughts, feelings, and attitudes. The mind has the power of being able to make one's student spirit. He will study hard to stay up to achieve success. The mind also has the opposite power: making a student dislike of the lessons and the teacher. He does not have the spirit to achieve achievement to get a low score and not go up the class. That's the chain that keeps turning: thoughts, concentration, feelings, attitudes and results. 


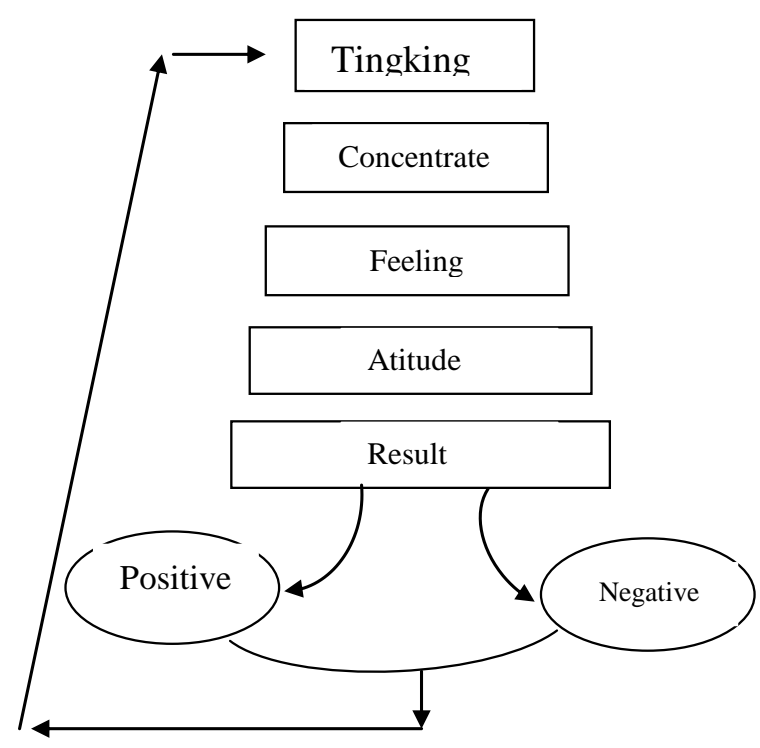

In the picture above explains that thoughts, feelings and attitudes can affect results. Elfiky (2015: 40) explains that the mind affects reason and makes it concentrate on a meaning that can affect one's feelings. There is a burning feeling and there is a calm according to the mind that exists. Feeling is fuel for the attitude that people use in moving their bodies, expressing their faces, and talking. All that bring results that want to be realized at that time.

Based on the result of hypothesis test showed that there is a significant influence between self concept and mathematics learning achievement of grade $X$ State Senior High School 14 Medan which obtained from tcount $(3,572)>$ ttable (1.68), with probability significance $0,01<0,05$. The amount of contribution (contribution) from self concept variable to learning achievement equal to $25,1 \%$. The low contribution (contribution) gained is influenced by many other factors that can affect the learning achievement that is not examined in this research either from internal or external factors such as: interest, talent, motivation and so on. This is in line with the research Sagita Suryade (2014) which states that there is influence self-concept on student achievement with the acquisition of $r$ value of 0.766 . The final result shows that $0.217<0.766>0.283$ with a significant level of $5 \%$. The amount of contribution (contribution) from self concept variable to achievement learn equal to $58,7 \%$. 


\section{CONCLUSION}

Based on the results of hypothesis analysis and testing shows that there is a significant influence between self-concepts on mathematics learning achievement of students class X State Senior High School 14 Medan. With the more positive self-concept of students, the higher the students' mathematics learning achievement. Based on the conclusions, can be given some suggestions as follows: students are expected to be more active learning as an effort to increase knowledge and skills. Thus, students can master the material in learning mathematics, teachers should pay attention to the way of delivery of material for easy to understand and can foster students' self confidence so that students are more confident in the ability to solve mathematical problems and do not feel afraid in learning mathematics.

For the next researcher is expected to be more accurate in the preparation of questionnaire so as to get better results also and expected for further researchers to examine other factors that affect learning achievement in addition to self-concept because based on the amount of contribution produced by researchers is still small, so there are many factors others not examined in this study such as motivation, interest, talent and so forth.

\section{BIBILIOGRAPHY}

Abdurrahman, M. 2012. Pendidikan Bagi Anak-anak Berkesulitan Belajar. Rineka Cipta. Jakarta.

Andinny, Yuan. 2013. Pengaruh Konsep Diri dan Berpikir Positif terhadap Prestasi Belajar Matematika Siswa. Jurnal: Fakultas Teknik, Matematika dan IPA Universitas Indraprasta PGRI.

Elfiky, Ibrahim. 2015. Terapi Berpikir Positif. Jakarta: Zaman.

Hutagalung, Inge. 2007. Pengembangan Kepribadian. Jakarta: PT Indeks.

Ihsan, Fuad. 2005. Dasar-dasar Kependidikan. Jakarta: PT Rineka Cipta.

Khodijah, Nyayu. 2014. Psikologi Pendidikan. Jakarta: PT Raja Grafindo Persada.

Margono S. 2009. Metodologi Penelitian Pendidikan. Jakarta: PT Rineka Cipta. 
Paulus, Alexander. 2007. Success in Life Through Positive Words, Jakarta: PT Gramedia Pustaka Utama.

Purwanto, Ngalim. 2010. Psikologi Pedidikan. Jakarta: PT Remaja Rosdakarya.

Rakhmat, Jalaluddin. 2005. Psikologi Komunikasi. Bandung: PT Remaja Rosda Karya

Riduwan. 2010. Skala Pengukuran Variabel-variabel Penelitian. Bandung: Alfabeta.

Rohmah, Lailatul. 2012. Hubungan Antara Berpikir Positif dengan Kepatuhan pada Aturan. Skripsi: UIN Maulana Malik Ibrahim. Malang.

Slameto. 2010. Belajar dan Faktor-faktor yang Mempengaruhi. Jakarta: Rineka Cipta

Sobur, Alex. 2013. Psikologi Umum. Bandung: Pustaka Setia.

Soemanto. 2006. Psikologi Pendidikan. Jakarta: Rineka Cipta

Sugiyono. 2011. Statistika untuk Penelitian. Bandung: Alfabeta.

Suharsimi, Arikunto. 2013. Dasar-dasar Evaluasi Pendidikan. Jakarta: Bumi Aksara.

Sukardi. 2009. Metodologi Penelitian Pendidikan. Jakarta: PT Bumi Aksara.

Syofian. 2014. Statistika Parametrik untuk Penenlitian Kuantitatif. Jakarta: Bumi Aksara.

Tentama, F. 2010. Perpikir Positif dan Penerimaan Diri pada Remaja Penyandang Cacat Tubuh Akibat Kecelakaan, Humanitas.

Thalib, Syamsul Bahcri. 2010. Psikologi Pendidikan Berbasis Analisis Empiris Aplikatif". Jakarta: PT Kencana Prenada Media Group.

Truna, Dody S dan Rudi Ahmad Suryadi. 2013. Paradigma Pendidikan Berkualitas. Bandung: Pustaka Setia.

Wahab, Rohmalina. 2015. Psikologi Belajar. Jakarta: PT Raja Grafindo Persada 